\title{
Climate change impacts on pest ecology and risks to pasture resilience
}

\author{
Sarah MANSFIELD ${ }^{1, *}$, Colin M. FERGUSON ${ }^{2}$, Philippa J GERARD ${ }^{3}$, David HODGES ${ }^{4}$, \\ John M. KEAN ${ }^{3}$, Craig. B. PHILLIPS ${ }^{1}$, Scott HARDWICK ${ }^{1}$ and Sue M. ZYDENBOS ${ }^{1}$ \\ ${ }^{1}$ AgResearch, Lincoln Science Centre, Private Bag 4749, Christchurch 8140, New Zealand \\ ${ }^{2}$ AgResearch, Invermay Agricultural Centre, Private Bag 50034, Mosgiel 9053, New Zealand \\ ${ }^{3}$ AgResearch, Ruakura Research Centre, Private Bag 3123, Hamilton 3240, New Zealand \\ ${ }^{4}$ DairyNZ Private Bag 3221, Hamilton 3240, New Zealand \\ *Corresponding author: Sarah.Mansfield@agresearch.co.nz
}

\begin{abstract}
Highlights
It is well understood that damage by insect pests can have serious consequences for pasture resilience. However, the impacts of climate change on pastoral systems, the responses of insect pests, and implications for pest impact mitigation are unclear. This paper reviews pest responses to climate change, including direct impacts such as temperature and carbon dioxide levels, geographic range expansion, sleeper pests, and outbreaks resulting from disturbance such as drought and farm system changes. The paper concludes with a plea for transdisciplinary research into pasture resilience under climate change that has insect pests as an integral component - not as an afterthought.
\end{abstract}

Keywords: agricultural system, biological control, insect, invertebrate

\section{Background}

Populations of insect pests and their impacts on pastoral farming result from multiple interacting factors including climate, pasture species, cultivars and symbiotic endophyte fungi, natural enemies, plant nutrient status, soil fertility and moisture levels, soil type, stock type and management, pasture management, cropping and pasture renovation practices and farmer awareness of pest issues (see Ferguson et al. (2019) for a substantive review of pasture insect pests). For instance, a porina (Wiseana spp.) population in an optimally fertilised, properly grazed, 5-year-old AR37 ryegrass-clover pasture established by direct drilling and not allowed to become rank when porina moths are laying eggs, will be regulated by reduced egg hatch and survival of young larvae, naturally occurring pathogens, and endophyte toxins. At the same time healthy plants will tolerate porina feeding more than if they were under nutrient stress and over grazed. This will differ substantially from a porina population in a 3-year-old AR1 pasture established after cultivation, closed to grazing during egg laying and hatch, but heavily stocked during winter, where natural population regulation will be very low, and the ryegrass unprotected by the endophyte. The latter could be further compromised if soil fertility is also low. Reasonable estimates of porina densities for these scenarios would be 15 and 150 larvae $/ \mathrm{m}^{2}$, respectively. However, climate is also a key driver for pest populations, which are often strongly affected by climatic extremes, e.g., summer droughts frequently disrupt natural controls of porina and grass grub (Costelytra giveni) leading to major pest outbreaks in following years (East \& Willoughby 1980; Kalmakoff et al. 1985).

Despite the importance of climate, and therefore climate change, as drivers of pest populations, few studies have investigated and predicted climate change impacts on farm systems in New Zealand and none have directly addressed either the impact of climate change on New Zealand pasture insects, or their effects on future farm systems. Dynes et al. (2010) concluded that dairy farming in Manawatu had considerable adaptive capacity in relation to climate change scenarios and that the ingress of $\mathrm{C}_{4}$ grasses would potentially alter the system through declining pasture quality; this change would also provide opportunities for invasion by new pests, such as tropical grass webworm. Kalaugher et al. (2013) presented a mixed-methods framework designed to assess the adaptive potential of dairy farming systems from both bottom-up (qualitative social research with farmers and communities) and top-down (quantitative biophysical modelling) perspectives. Using this approach, Kalaugher et al. (2017) simulated climate change impacts for six pasture-based dairy farms located across New Zealand, finding that average annual pasture production ranged from no change to an $18 \%$ decrease. While the biophysical modelling did not include potential insect pest impacts, significant concerns were raised through the farmer-focused analyses, particularly relating to changes in pasture species and the potential for incursion of new insect pests. Lieffering et al. (2016) modelled the impacts of climate change on two sheep and beef farming systems under six different management regimes. A key finding was that while there was minimal impact on total annual pasture growth, there were marked changes in the seasonality of pasture production and significant regional differences in the farm-scale economic 
impacts. Unfortunately, this study did not consider the effect of insect pests, but the authors concluded that factors like this should be included in future analyses as they could significantly alter farm performance.

Due to the lack of systems-level studies of insect impacts on pastoral farm systems in New Zealand, climate change impacts must be inferred by direct impacts on insect biology or pasture production, which is the approach taken in this paper. Our primary focus is on pasture pests already present in New Zealand and how these pests may respond to climate change. Selected pests are used as case studies to illustrate each potential response to climate change, where the potential types of response to climate change are drawn from the international literature.

\section{Pest responses to climate change}

Insects and other arthropods are ectotherms: their body temperature and metabolism are determined by the climate, particularly temperature, that they experience. For pests, and their associated natural enemies, climate affects geographic range, habitat suitability, responses to disturbance arising from extreme events such as drought, annual number of generations, and abundance. In temperate climates, pests that are limited by cool temperatures are predicted to expand their geographic range as global average temperatures increase. This is demonstrated by fall armyworm that recently invaded Australia (Du Plessis et al. 2020), tropical grass webworm (Hardwick et al. 2000) and black beetle, one of the case studies presented below.

Insects with restricted geographic ranges and/or low abundance may respond to climate change by increasing their distributions, abundance and impacts if the changes provide more favourable conditions. The potential of these 'sleeper' pests, particularly exotic scarabs, to damage New Zealand pastures was highlighted by Jackson \& Klein (2006) and Townsend et al. (2008). Case study subjects in this contribution are the redlegged and blue oat earth mites, both of which are already major pests in Australia (Bailey 2007) and are already present in New Zealand (Scott 1984).

The frequency and severity of extreme climate events (droughts, heatwaves, floods, etc.) are also expected to increase as the average global temperature increases. Pest survival and abundance are affected by climate extremes, which may lead to more frequent outbreaks if these extreme events create favourable conditions for pests, or unfavourable conditions for their natural enemies. For example, La Niña events have been associated with black beetle outbreaks because the warmer northerly winds they bring favour this pest (Gerard et al. 2013b). Climate extremes may also disrupt pest-natural enemy interactions, again favouring pest outbreaks (Goldson 2006; Gerard et al. 2013a; Schreven et al. 2017). Flores weevil, a littleknown pasture pest, responds positively to climate disturbance so was selected as a case study. In the central North Island, recent outbreaks of porina are attributed to the loss of natural population regulation due to drier than average summer/autumn conditions and this is also discussed.

While some New Zealand pasture pests have only one generation per year (e.g., porina, manuka beetle, lucerne weevil), some have multiple generations each year, including Argentine stem weevil, clover springtail, and clover root weevil. Species that have multiple generations may respond to climate change by completing additional generations within a year (Figure 1). The impacts of such a change are explored using diamondback moth as a case study.

Climate change will affect more than just temperature and direct metabolic responses of pests to temperature changes. Plants respond not only to temperature but also to increased $\mathrm{CO}_{2}$ levels in the atmosphere, leading to changes in growth rates and their $\mathrm{C}: \mathrm{N}$ ratios (Ainsworth \& Long 2005; Ainsworth \& Rogers 2007). In turn, this affects the nutritional quality of the plant for herbivores (Fajer et al. 1989). Insect herbivores respond to these combined changes (Zvereva \& Kozlov 2006; Massad \& Dyer 2010) as do their associated natural enemies (Coll \& Hughes 2008; Gerard et al. 2013a). Hence climate change influences entire ecosystems with all their complex interactions between trophic levels. It is more challenging to gather experimental data regarding $\mathrm{CO}_{2}$ impacts on insects than it is to study temperature effects because it is technically more difficult and costly to create artificial atmospheres with different levels of $\mathrm{CO}_{2}$. As a case study, we present recent data about the impact of enhanced $\mathrm{CO}_{2}$ levels on porina, which show that the effects are not straightforward.

In the long term, system-wide changes in pastoral farming will be needed to adapt and respond to climate change. Any increase in land area planted with alternative forage crops will provide more habitat for their associated pests. For example, if lucerne plantings increase because their deep roots provide a degree of drought tolerance, this will increase habitat for pests such as lucerne weevil and whitefringed weevil (Naupactus leucoloma). This paper is primarily focused on pest responses to climate change rather than changes at the farm system level. We do, however, explore possible system-wide changes using the recent adoption of plantain and its emerging moth pests as a case study.

\section{Geographic range expansion: black beetle (Heteronychus arator)}

Black beetle is native to Africa where it is now distributed in southern, central and eastern regions north to Ethiopia, and has been accidentally introduced 


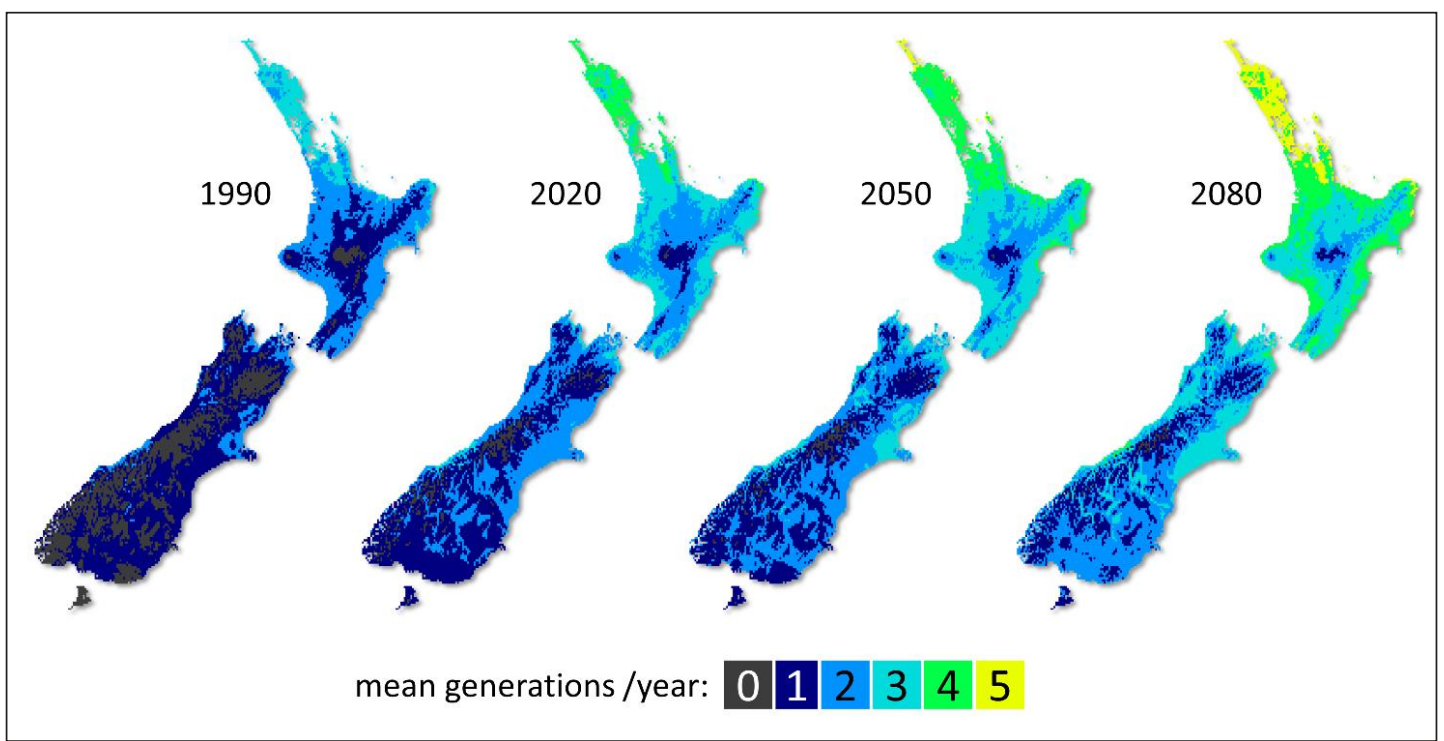

Figure 1 Change in number of generations per year of Argentine stem weevil, at 30-year intervals from 1990 to 2080 under moderate warming (scenario A1B; IPCC 2000).

to Australia, New Zealand, and Norfolk Island (Anon 2020). It has one generation per year, and in New Zealand its populations are regulated by interactions primarily between pasture species (Bell et al. 2011), temperature, rainfall (Watson 1980; King et al. 1981a, b), soil type (De Klerk 2015), and natural enemies (Bell et al. 2011). Here, we focus primarily on the climatic determinants of black beetle's abundance and distribution because these are the variables most immediately influenced by climate change, though the abundance and distribution of black beetle's host plants and natural enemies will also respond to climate change.

Temperatures $>15{ }^{\circ} \mathrm{C}$ are needed for black beetle flight and oviposition (Watson 1980), optimum egg and larval development, larval feeding, and growth (King et al. 1981b). Particularly important are spring temperatures which, when low, inhibit adult flights from overwintering sites to oviposition sites, thus impeding oviposition in the habitats most suitable for larval development (Watson 1980). Low spring and summer temperatures also extend development of eggs and larvae, which may increase disease incidence and accentuate mortality of larvae (King et al. 1981b). Protracted development of larvae during summer reduces the proportion of the population that reaches the adult stage before the following winter (Watson 1980), and those beetles forced to endure winter as larvae are unlikely to survive (see below).

Adults and eggs of black beetle are relatively tolerant of high soil moisture, whereas larvae are not. Thus, Watson (1980) concluded that black beetle generations 'are largely derived from those individuals that emerge in autumn and overwinter as adults'. Winter mortality of black beetle larvae is also high in winter-wet parts of southwest Australia (Matthiessen \& Ridsdill-Smith 1991). In spring, high rainfall tends to coincide with low temperatures, which together exacerbate mortality of larvae in spring and summer (Watson 1980; King et al. 1981b). Such mortality is less significant in southwest Australia where wet, cool springs are uncommon (Matthiessen \& Ridsdill-Smith 1991).

Despite black beetle's sensitivity to climatic vagaries, its current enormous African distribution is testimony to its adaptability and resilience, considering its historic range was limited to South Africa (Abdallah et al. 2016). In South Africa alone, it occurs both in regions with winter-wet climates and those with winterdry climates (Harrington 1964; Kleynhans et al. 2005). In the former it overwinters predominantly as an adult and in the latter as a larva (Petty 1976 and Taylor 1951, cited in Watson 1980).

Watson (1980) observed that in New Zealand black beetle generally occurred in locations with mean annual surface temperatures $>12.8{ }^{\circ} \mathrm{C}$. Based on data from Garnier (1958, cited in Watson 1980), these included the North Island north of approximately Te Awamutu and coastal regions of Manawatu, Taranaki, Hawke's Bay, East Cape and Bay of Plenty (Watson 1980). Using temperature data from the National Institute of Water and Atmospheric Research (NIWA) for 19712000, Bell et al. (2011) noted this area had increased to include the North Island north of about Tokoroa, a strip along the east coast around East Cape south to Cape Kidnappers, and a strip of the west coast south 


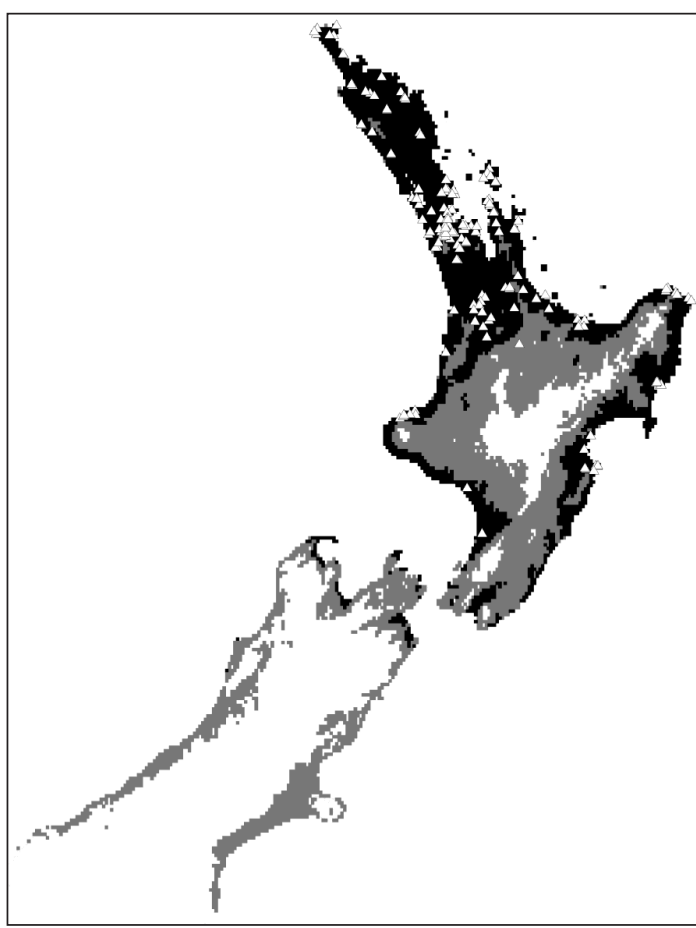

Figure 2 New Zealand locations with annual mean temperatures $\geq 12.8^{\circ} \mathrm{C}$ based on data for 19702000 (black fill), and a climate projection (scenario RCP 6.0; Hijioka et al. 2008) for 2041-2060 (grey fill). Based on the climate projection, the unfilled areas will have mean temperatures $<12.8{ }^{\circ} \mathrm{C}$ during 2041-2060. Field records for black beetle, Heteronychus arator, are marked with white triangles.

to Whanganui. We largely replicated results from Bell et al. (2011) using temperature data for 1970-2000 from WorldClim (Fick \& Hijmans 2017), though our result also included parts of Manawatu, Wairarapa, and small areas on the northern fringes of Marlborough and Tasman (Figure 2, black fill).

To date, black beetle has been recorded from locations in the North Island as far south as Foxton and Hawke's Bay (Figure 2, white triangles), and these empirical observations of its distribution in New Zealand conform well to the predictions of the Watson (1980) model (i.e., in Figure 2, all but one of the 247 white triangles coincide with black filled areas). Its apparent absence from the warmer areas of Wairarapa (Figure 2) may be due either to limitations of the model, slow southward dispersal by black beetle, insufficient sampling, or unknown impediments to black beetle's establishment and persistence there.

To illustrate a possible effect of climate change on black beetle's distribution in New Zealand, we calculated locations predicted to have mean annual surface temperatures $\geq 12.8^{\circ} \mathrm{C}$ (Watson 1980) by about
2050 using a future climate scenario for 2041-2060 (scenario RCP 6.0; Hijioka et al. 2008). This indicated areas with temperatures $\geq 12.8{ }^{\circ} \mathrm{C}$ may expand over the next 20-40 years to include much of the North Island and coastal parts of Marlborough, Tasman, Canterbury and Westland (Figure 2, dark grey fill). Black beetle would likely find conditions suitable for population persistence in all these regions except parts of Westland where high rainfall, which is expected to intensify further with climate change (Ministry for the Environment 2019), might cause high mortality.

Black beetle is already the second most economically damaging pasture pest in New Zealand (Ferguson et al. 2019), with only limited control options (Mansfield et al. 2019). It is vital that black beetle is investigated alongside any development of subtropical grasses as future forages in northern New Zealand because these are favoured host plants. Furthermore, climate-related life cycle changes should be investigated in Northland and Waikato to model at the farm level what these changes will mean for pasture damage across black beetle's current and future New Zealand range.

\section{Sleeper pests: earth mites}

\section{(Halotydeus destructor and Penthaleus spp.)}

New Zealand is vulnerable to biological invasions with at least 1477 non-native insects having become established by 2018 (Edney-Browne et al. 2018). While a few have become serious pests (Walker et al. 2017; Goldson et al. 2020), the majority are innocuous. However, some may be "sleeper pests" that will start to cause damage in response to changes in their environment (Hulme 2017; Frank \& Just 2020).

The earth mites, redlegged earth mite (RLEM) and blue oat mites (BOM), are pests of various crop and pasture species in New Zealand and southeastern Australia. Earth mites damage plants by feeding on the upper surface of cotyledons and leaves where they penetrate the cell membrane to suck out the cell contents. Plants are most at risk in autumn-spring with germinating plants being at the greatest risk (RidsdillSmith 1991). Densities of adult earth mites can reach 15000 per $\mathrm{m}^{2}$. These species are significant pests of crops, including subterranean clover and lucerne, in Australia, costing the sheep and beef industries AUD $\$ 137-193 \mathrm{M}$ per annum (Ridsdill-Smith 1991). In New Zealand, they are currently only minor, occasional, or localised pests.

Earth mite larvae, nymphs and adults are active in the winter and spring, but as summer temperatures rise and moisture levels drop, the eggs aestivate in the dead bodies of adult females (Ridsdill-Smith 1997). The phenology of RLEM is well understood: egg hatch is triggered by a significant rainfall event combined with a period of 7-10 days where the mean daily maximum 
temperature is below $21^{\circ} \mathrm{C}$ (Ridsdill-Smith et al. 2005). The larvae reach maturity in 60-80 days, and after mating each female lays approximately 75 eggs that will hatch in 7-14 days. In New Zealand there are three generations per year (Scott 1984). Modelling of the Australian distribution of RLEM by Hill et al. (2012a) indicated that the New Zealand distribution of this pest will expand on the east coast of the North and South Islands under future climate change scenarios.

While the phenology of BOM is similar to that of RLEM, there are key differences that inhibit precise predictions of the effect of climate change on its future distribution. In Australia, BOM was considered to be a single species, Penthaleus major, prior to 1995 . However closer examination showed that BOM was a complex of at least three species $-P$. major, $P$. falcatus and $P$. tectus - that are morphologically cryptic and, unlike RLEM, reproduce via obligate parthenogenesis (Weeks et al. 1995; Weeks \& Hoffmann 1999). There are clear differences in the biology and ecology of each BOM species including differences in host plants (Umina \& Hoffmann 2004), the timing of diapause and egg production (Umina \& Hoffmann 2003), and pesticide tolerance (Umina \& Hoffmann 1999; Weeks \& Hoffmann 1999). Hill et al. (2012b) mapped the distributions of the three BOM species, which were characterised by different sets of climatic variables. In Australia, suitable climate space for all three species was predicted to decrease under the climate change scenarios investigated, and the assemblage of BOM species is predicted to change, particularly in Western Australia, South Australia and Victoria (Hill et al. 2012b). In New Zealand, the questions about whether BOM consists of a single species or complex of two or more species and their distribution(s) remain unanswered. It is therefore impossible to predict how BOM's future distributions and impacts in New Zealand will respond to climate change. Key first steps to understanding potential risks from BOM are to confirm the species present in New Zealand and define their distributions. These data could then be used to test predictions from the Australian models for New Zealand under its current climate and, if reasonable, evaluate BOM's potential future New Zealand distributions under future climate scenarios.

\section{Outbreaks in response to disturbance: Flores weevil (Floresianus sordidus)}

Most biological control systems are susceptible to disturbance. Therefore, predicted changes in frequency and magnitude of climate extremes induced by climate change (Ministry for the Environment 2018) may be more ecologically significant than changes in mean conditions. Droughts, floods and disturbances generally are followed frequently by pest outbreaks. Climate change is believed to underlie the extreme drought and

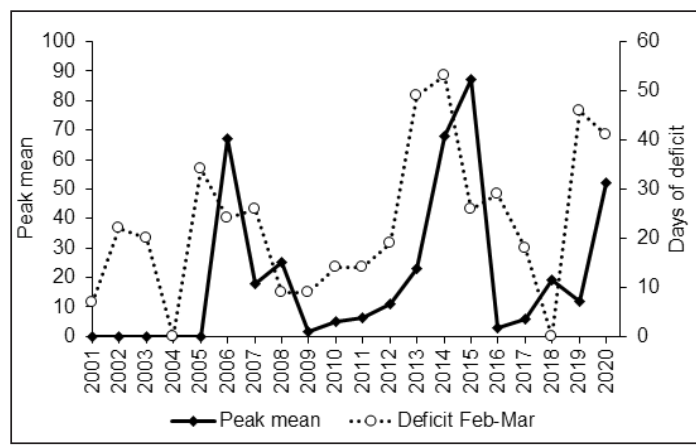

Figure $3 \quad$ Number of days of soil water deficit in February and March and peak monthly mean number of weevils in samples collected in Waikato.

precipitation events that triggered the massive 2020 locust plague devastating Ethiopia, Somalia and Kenya, and extending across the Red Sea into Southwest Asia (Peng et al. 2020). In New Zealand, outbreaks of grass grub and porina often occur in pasture 2-4 years after a severe drought, similar to the population peak seen several years after sowing (East \& Willoughby 1980; Kalmakoff et al. 1985). This peak occurs because drought also kills pathogens associated with these pests and the pathogens are slower to recover from disturbance events than the pests themselves, leading to low infection rates in the next few generations (O’Callaghan et al. 1989).

Flores weevil is native to Argentina, Uruguay and Brazil (Lanteri et al. 2013) and was first discovered in Hawke's Bay in 1972, when causing severe damage to pasture (Essen 1975). While assessing weevil biocontrol in Waikato, researchers observed that Flores weevil adults had become very common in pasture from 2006 onwards. A retrospective search was made into historic Waikato weevil suction sampling records to assess if this species is an "awakening" sleeper pest or merely an invasive species establishing in a new favourable region. A total of 284 hard copy data sheets dating from 1991 to 2019 had recorded weevil catches down to species level.

The first Waikato record of this flightless weevil was a single adult at Hamilton airport in April 1995. Since then, there has been a close relationship between the number of days of soil water deficit (DSD) recorded during February and March at the Ruakura Research centre meteorological station (NIWA 2020) and the peak number of weevils found in Waikato samples the following year (regression analysis $\mathrm{F}<0.0001$, Figure 3 ).

Flores weevil is not a rapidly invasive species but is a successful colonizer, like other parthenogenic polyphagous weevils in the same Naupactini tribe from South America, e.g., whitefringed weevil and Fuller's rose weevil (Naupactus cervinus, Rodriguero et al. 
2019). One of the most important factors influencing the Flores weevil's distribution worldwide is the mean temperature of the driest quarter (Lanteri et al. 2013). It is likely that the shift from being a rare to a common species in Waikato is linked to climate change and the observed increase in the frequency and intensity of droughts in the region. During the 1970s, Ruakura recorded only one season (1977-78) with over 65 days of DSD and none in the 1980s (NIWA 2020). There were two consecutive dry seasons during the late 1990s (1997-98 and 1998-99), three in the late 2000s and five from 2010. The last five droughts have been longer, averaging $89 \pm 5 \mathrm{DSD}$, whereas the only drought between 1970 and 2010 that exceeded 80 DSD was in 2005-06 (98 DSD). While the exact relationship is unknown, it is possible that droughts increase the abundance of favoured host plants in pasture during the autumn adult emergence, such as plantain and clovers, enabling better adult survival and greater larval recruitment. If the trend towards increasing drought frequency and severity continues to be associated with outbreaks of Flores weevil, and these outbreaks accentuate the impact and ability of pastures to withstand and recover from droughts, then pest management advice will need to be developed to take this pest into account.

\section{Increased number of generations: diamondback moth (Plutella xylostella)}

Diamondback moth is a cosmopolitan pest of vegetable and forage brassicas (Talekar \& Shelton 1993). It is a multivoltine pest with the number of generations per year determined primarily by local weather conditions, although food availability is also important for this brassica specialist. Diamondback moth does not diapause over winter: instead, its development slows until warmer temperatures resume. Mortality does increase with extended cold periods $\left(<5^{\circ} \mathrm{C}\right)$, but migration from warmer regions allows diamondback moth to recolonise suitable habitats in spring and summer (Macfadyen et al. 2018). In tropical climates, diamondback moth can have up to 20 generations per year. In temperate climates, 4-6 generations per year is common but this can increase under favourable conditions (Dancau et al. 2018). The CLIMEX model created by Zalucki et al. (2012), when applied to New Zealand climate conditions, predicts one additional generation per year by 2070 (Figure 4), typically from 4-8 generations to 5-9 generations annually with the number of generations decreasing from north to south.

An increase of one generation per year may appear small, but in other multivoltine species a small increase in the number of generations may be enough to shift the pest population into a severe outbreak (De Barro 1995, 2002). With increased generations per year,

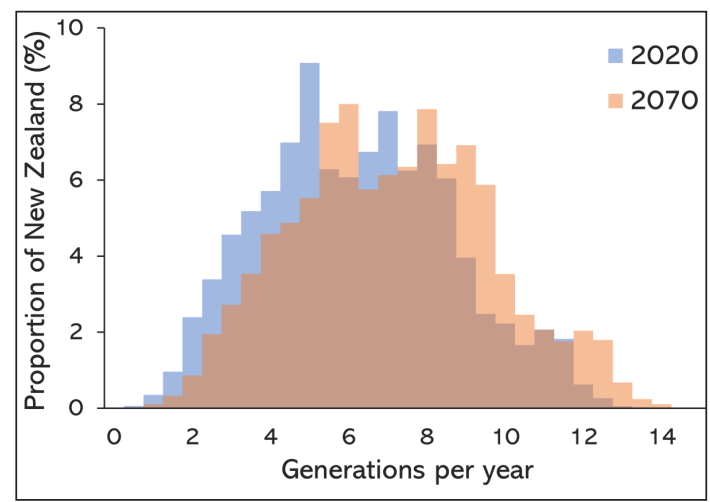

Figure 4 Predicted number of generations per year of diamondback moth in New Zealand in 2020 and 2070 under scenario A1B (moderate warming, IPCC 2000). Brown shading indicates overlap between 2020 (blue) and 2070 (orange) predictions.

population build up in forage brassica crops during the warmest seasons is likely to increase, although current data are inadequate to predict the magnitude of change in abundance for New Zealand. It is also likely that diamondback moth will appear in crops ca. 1 or 2 months earlier than currently, particularly in southern New Zealand. These changes pose greater risks of crop damage and farmers may increase their use of insecticides in response. In turn, this will increase the risk of insecticide resistance developing because diamondback moth has evolved resistance against all insecticide classes it has been exposed to (Shelton et al. 1993; Liu et al. 2003; Eziah et al. 2008): New Zealand populations have a similar propensity (Cameron et al. 1997; Walker et al. 2012). Integrated pest management (IPM) is recommended to reduce reliance on insecticides, minimise the risk of resistance and maintain control of diamondback moth (Walker et al. 2016; Horrocks et al. 2018). For pastoral farmers who use forage brassicas regularly as part of their feed supply, particularly in cooler southern regions, greater awareness of this pest and careful consideration of control options to minimise the risk of insecticide resistance will become more important. Agrichemical suppliers, the seed industry and farm advisers can help by providing updated advice that reflects changes to local diamondback moth populations, perhaps by drawing on advice and tools developed for the vegetable brassica sector, which will face similar challenges.

An important component of IPM for diamondback moth is the impact of natural enemies. In New Zealand these include two introduced parasitoids, Diadegma semiclausum and Diadromus collaris (Talekar \& Shelton 1993; Walker et al. 2016). There is no published information regarding climate change responses of $D$. 
collaris, but climate models and experiments suggest that $D$. semiclausum is more vulnerable to higher temperatures than diamondback moth and that this may lead to reduced parasitism rates in response to climate change (Dosdall et al. 2012; Furlong \& Zalucki 2017; Schreven et al. 2017). If control by natural enemies is reduced, in combination with more pest generations per year, then again, the risk of significant crop damage increases. Diamondback moth is just one example that demonstrates how a comparatively simple response to climate change in the pest population can lead to other associated changes, which act to multiply the risk of pest damage.

\section{$\mathrm{CO}_{2}$ impacts on plants and herbivores: porina (Wiseana spp.)}

The Wiseana species/subspecies complex is a group that we expect to adapt to climate change. The first aspect of their response, as with other insect pests, will be a direct response to increased temperature and climatic variability, which will in turn influence their management. The second aspect of their response relates to the effects of increased $\mathrm{CO}_{2}$ levels on plant growth. Both aspects are addressed here.

Of the seven porina species forming the complex, five are recognised as inhabiting pasture. Of these, $W$. mimica, $W$. jocosa and $W$. fuliginea are restricted to the South Island (Dugdale 1994) and little is known about the effect of temperature on their behaviour or development. More is known about the two most common, widespread, and damaging species, $W$. copularis and W. cervinata (Ferguson \& Crook 2004; Atijegbe 2019). These occur throughout both islands between $37^{\circ} \mathrm{S}$ and $47^{\circ} \mathrm{S}$ with adventive populations on the Chatham Islands (Dugdale 1994; Ehau-Taumaunu 2017). Both species consist of two haplotypes: the northern haplotype of $W$. cervinata appears restricted to the North Island and the southern haplotype to the South Island. However, while southern haplotype $W$. copularis has only been found in the South Island, northern haplotype W. copularis is found in the North and South Islands, but adult flight times (and consequently larval development) for the northern haplotype differ by up to 8 weeks between islands (Richards et al. 2017).

Wiseana cervinata appears more adapted to cooler climates and $W$. copularis to warmer temperatures. The ability to easily identify larvae from pasture and to distinguish between haplotypes is a recent achievement (Richards et al. 2017) and therefore ascribing behaviours at haplotype level is still limited. As a generality, however, $W$. cervinata flies predominantly in mid to late spring in the South Island with small numbers seen into mid-summer. This translates into pasture damage becoming apparent in May-June. In the North Island the main flights of this $W$. cervinata can occur either in early summer, similar to the South Island, or early to mid-autumn, in which case damage may not show until July-August. For example, at Makuri, in the Tararua District, $W$. cervinata was recorded flying between 18 October 2012 and 9 March 2013 but $70 \%$ of the total catch from a light trap occurred between 21 February and 8 March. The southern haplotype of $W$. copularis flies in late spring in the South Island with damage showing in May-June and the northern haplotype flying in mid-summer (damage in June-July) while in the North Island this northern haplotype flies in late summer to early autumn (e.g., Ferguson et al. 2016) resulting in July-August damage.

For both species, the late summer/early autumn flight times of the northern haplotype are probably mechanisms that allow the vulnerable egg and $1^{\text {st }}$ instar larval stages to avoid hostile mid-summer temperatures. If climate change leads to warmer, drier summers becoming more prevalent, these phenomena could become more common further south, in which case southern North Island and northern South Island farms will experience a change in the pattern of damage as later egg laying shifts larval damage to later in the year. With this comes a change in management practices as applications of diflubenzuron will need to be applied later than currently. The timing of organophosphate insecticide application is less critical, but these are under increasing pressure to be removed from use and this pressure seems likely to increase coincidently with a warming climate. Farmers may, therefore, face a period of change, and if taken unawares, left without recourse to a "heavy handed" but effective tool for management of porina. The key to overcoming this issue lies with a wider understanding of porina biology, particularly changing development due to climate change, so that farmers can be kept informed when mitigation should be implemented. This is an area where consultants, seed and agrichemical industries could usefully play a role.

A further consequence of later porina development may result from their interactions with ryegrass endophytes. As the damaging larval stages develop later in winter, their feeding pressure coincides with a reduction in expression of epoxy-janthitrems produced by the AR37 endophyte, that otherwise offers protection from porina. It is thought that current instances of damage to AR37-infected pastures are due to a combination of high porina numbers, larvae resulting from late moth flights and low winter temperatures. As for grass grub and black beetle, endophyte development and selection are areas where there is considerable commercial investment and promise. Successful alignment of endophyte expression with climateinduced changes in grass and porina development could considerably alleviate porina pressure.

Porina are endemic species that, like grass grub, 


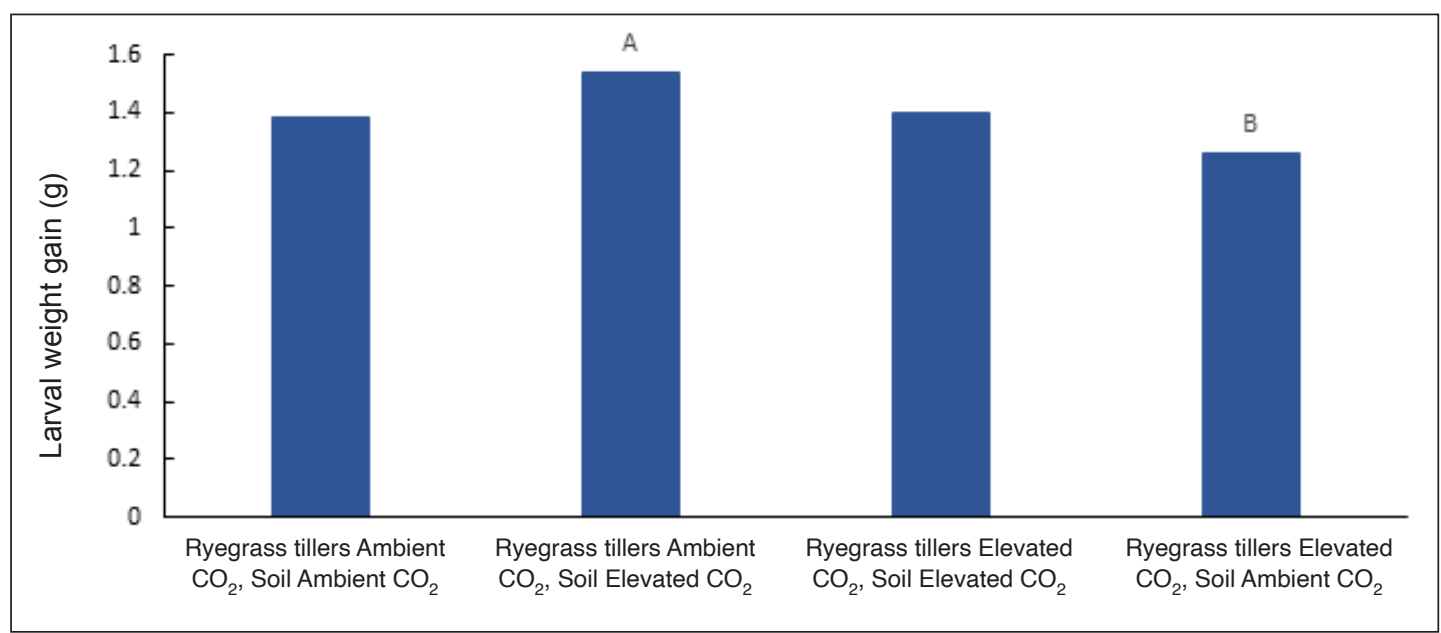

Figure 5 Weight gain of Wiseana copularis larvae reared in combinations of ryegrass tillers, air $\mathrm{CO}_{2}$ and soil $\mathrm{CO}_{2}$. Column marked $A$ is significantly different to column marked $B(P<0.05)$.

are subject to natural population regulation, primarily from their associated pathogens. The impact of climate change on such natural regulation is unknown but porina impacts in the Ruapehu District give an indication of what happens when frequent dry summers disrupt natural regulation. Here it is thought that periodic drier than average late summers caused porina populations to crash, with associated reductions of obligate pathogens. In the years following such crashes, high porina populations became common, causing widespread and severe damage. Just when natural population regulation was expected to re-establish, the onset of another dry period perpetuated the damage cycle. This pattern began in 2011 in the Ruapehu District and is continuing in 2020 , and the cost to individual farmers has been anecdotally reported at over $\$ 50,000$ p.a. Such situations may become increasingly common. In contrast, there may also be some reduction in the geographic range of porina associated with warming temperatures. While porina are currently found as far north as $37^{\circ} \mathrm{S}$ they are not regarded as a significant pest until approximately $38^{\circ} \mathrm{S}$. This boundary may move further south as drier conditions become unsuitable for porina.

The effects discussed above are noticeable when they occur, but other effects of climate change are less obvious. The New Zealand FACE experiment (Newton et al. 2014) has grown pastures under elevated (currently $500 \mathrm{ppm}$ during the photoperiod) and ambient $\mathrm{CO}_{2}$ levels since 1997. A bioassay investigated the effect of plants and soil from these two treatments on the survival and growth of $W$. copularis larvae. Survival was unaffected by the treatments. However, under laboratory conditions, larvae fed ryegrass tillers from the ambient $\mathrm{CO}_{2}$ treatment gained significantly more weight than those fed tillers from the elevated $\mathrm{CO}_{2}$ treatment $(\mathrm{P}=0.017)$, while those reared in soil from the elevated treatment gained more weight than those in ambient soil ( $\mathrm{P}=0.049$, Figure 5). Overall, these antagonistic plant and soil effects resulted in no net difference between $W$. copularis larvae in the field treatments. How common, and how important, such effects are on pasture pests is unknown, but these findings indicate that climate-induced changes may not always be obvious.

\section{System changes in response to climate change: plantain moths (Scopula rubraria and Epyaxa rosearia)}

Since the nationwide drought in 2007-08, there has been a decline in performance of non-irrigated perennial ryegrass (Lolium perenne) pastures in New Zealand, particularly in the northern North Island, which appears to be associated with the increased frequency of summer droughts (Dodd et al. 2018; Woodward et al. 2020). To combat this, farmers have looked to heat- and drought-tolerant forages to enhance production over summer (Tozer et al. 2016; Muir et al. 2019). One of these is narrow-leaved plantain (Plantago lanceolata). However, the change to broad acre use of this forage led to the emergence of two previously innocuous native plantain moths (Geometridae) as significant pests (Gerard et al. 2018a; Muir et al. 2019).

Following reports of severe damage and crop losses in late summer and autumn 2013, nine plantain crops in Manawatu and three in Waikato were visually inspected for plantain moth and caterpillar damage in late summer 2014. Plantain moths were observed on all stands. Moths reared from specimens collected from Manawatu were Scopula rubraria while in 
Waikato approximately 60\% were Epyaxa rosearia, $25 \%$ very similar to E. rosearia and $15 \%$ were $S$. rubraria (Philip \& Ferguson 2014). It was noted that the variation within E. rosearia was extensive (Pers. comm. B Patrick, Wildlands Consultants Ltd) and they postulated that $E$. lucidata, another New Zealand endemic species, may also be present. At three of the Manawatu sites caterpillar density was measured and mean densities of caterpillars per site were $1861 / \mathrm{m}^{2}$, $873 / \mathrm{m}^{2}$ and $5207 / \mathrm{m}^{2}$, respectively (Philip \& Ferguson 2014). The severity of plant damage was very patchy and very badly damaged plants were often found close to relatively undamaged plants. In general, it was observed 1-year-old stands were infested only lightly with plantain moths, whereas 2- and 3-year-old stands were prone to severe production losses.

Both E. rosearia and $S$. rubraria are specialist plantain herbivores that feed only on Plantago species and tolerate their defensive compounds, which deter other more generalist insect herbivores (Gerard et al. 2018b). New Zealand has 11 native species of Plantago, the most common of which, $P$. raoulii, is found in a wide variety of habitats over a large elevational range on all three main islands as well as several smaller offshore islands (Meudt 2012). The transformation of E. rosearia and $S$. rubraria from innocuous species to significant pests was a response to the vastly increased food supply. Consequently, farmers in vulnerable regions, such as Waikato, generally no longer grow plantain as a crop, and instead include it in pasture mixes (Dodd et al. 2019). However, plantain moths will remain a challenge as plantain is a major means to mitigate on-farm environmental impacts in the dairy industry. Plantain in irrigated pastures reduces nitrate leaching losses (Carlton et al. 2019) and increasing proportions of plantain in the diet decreases the amount of urine-nitrogen (N) (Woodward et al. 2012; Simon et al. 2019), a key source of nitrous oxide $\left(\mathrm{N}_{2} \mathrm{O}\right)$, a potent greenhouse gas. Plantain moths may limit industry targets of $30 \%$ plantain content in pasture unless plant breeders select for resilience to these pests during cultivar development (Gerard et al. 2018b). Currently farmers have no management options to control these pests. Ideally, pest-resilient plantain cultivars will be developed. However, if plantain moths continue to cause damage to plantain grown for forage, there may be sufficient demand to warrant formal insecticide registration and label claims for these pests. This would require industry investment to support data collection for registration purposes.

It is likely that plantain moth abundance is magnified by the increasingly common hot, dry summers. Laboratory studies show both $S$. rubraria and $E$. rosearia can have at least three generations per year and will multiply rapidly during hot summers (Gerard et al. 2018). When temperatures are well above average, such as in February and March 2013 (NIWA 2020 ), the moths may multiply so rapidly that they escape population regulation by their natural enemies. Larvae of both species are prone to infection by the fungus Beauveria and are parasitized by two introduced parasitoids (Meteorus pulchricornis and Trigonospila brevifacies) and at least three other unidentified species (unpublished data, PJ Gerard, AgResearch).

\section{Discussion}

The case studies above aimed to isolate and discuss representative impacts of climate change on pasture pest systems, but it must be acknowledged that all species will be affected by climate change in multiple different ways. It may be easy to isolate and illustrate how individual pasture pest species are expected to respond to shifting climate boundaries, host plant physiology or weather extremes, but it is much harder to predict how a single species, let alone a typical pest complex, might respond to combinations of climate change impacts. Uncertainties become compounded, and the farm systems of the future will certainly differ in more than just their local climates. This is an area where modelling has a role to play. If the impact of insect pests, and their population drivers, are incorporated in models that consider all variables in farm systems, including changing climate and weather patterns, then it may become possible to develop strategies that minimize outbreaks. This is especially relevant to the use of $\mathrm{N}$ to compensate for often unrecognised pest damage, where pest management strategies are not available, are not used effectively, or are disrupted by the unintended consequences of $\mathrm{N}$ application. Nitrogen use is becoming more regulated and if its role as a repair mechanism for pest damage is to continue, then the models must be able to define its use to prevent unacceptable consequences.

It is naïve to think we can predict exactly what the pasture pests of tomorrow will be, or even if our current challenges will continue. New pests will no doubt arrive to disrupt our pastoral ecosystems, potentially displacing or exacerbating current challenges. For example, the fall armyworm (Spodoptera frugiperda) has recently invaded Australia and will spread southwards as climate warming allows. This moth will almost certainly spread naturally to New Zealand as westerly weather patterns increase in frequency and strength, and its establishment will be facilitated by increasing climate suitability on the west coast of the North Island. Its main host plant, maize, is already widely grown but may increase in importance as a fodder crop, and climate change may allow fall armyworm to persist in maize crops as far south as Banks Peninsula (Figure 6). As a strong flier, the moth might spread to 


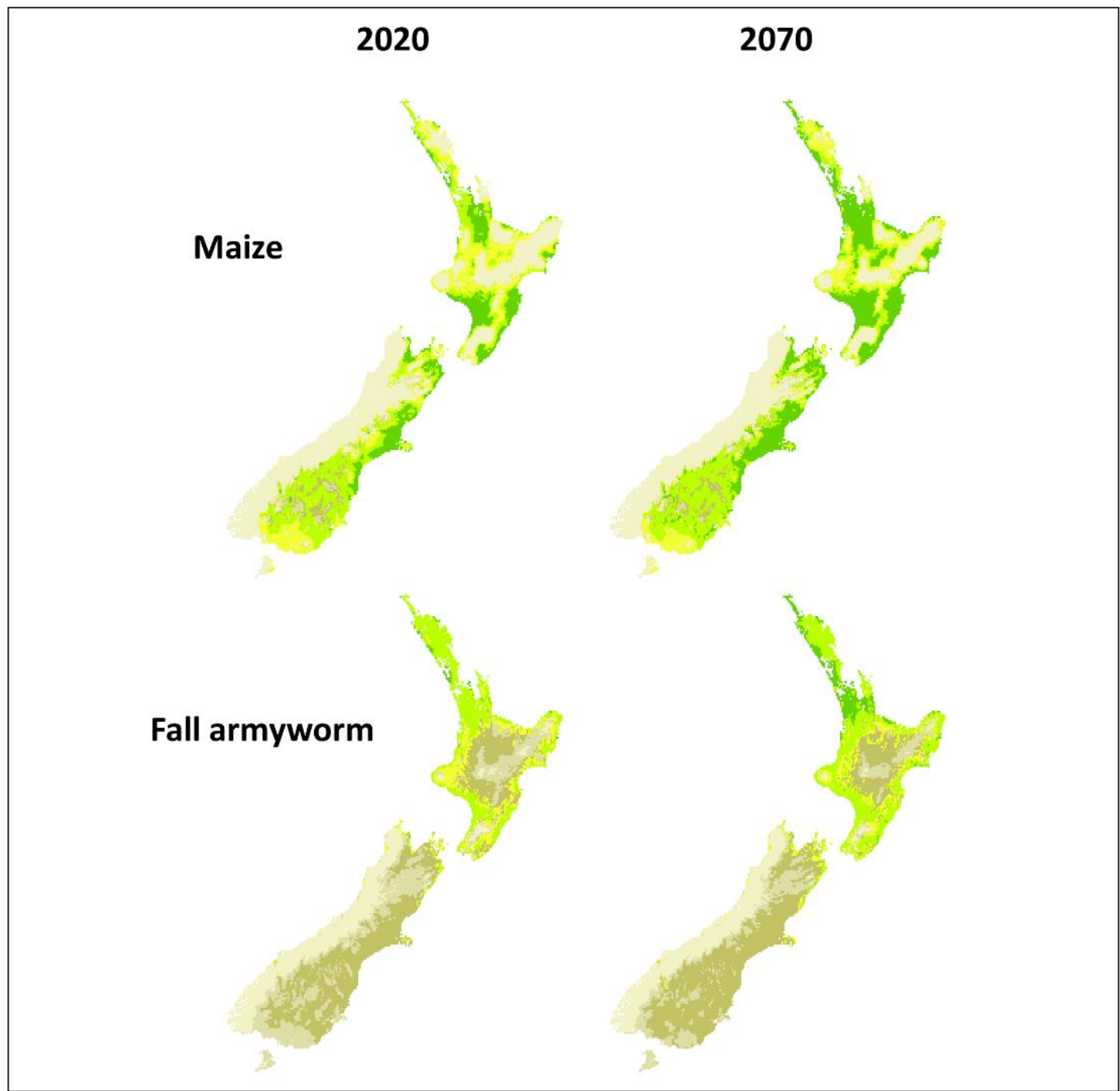

Figure 6 Projected climate suitability for maize (Ramirez-Cabral et al. 2017) and fall armyworm (Nagoshi et al. 2020) under 50 years of climate change. Dark green areas are favourable, light green are suitable, yellow are marginal, and brown areas may be seasonally suitable.

infest distant maize crops during summer, retreating to sufficiently warm havens in winter. In this example climate change may produce multiple effects on a pest, even without considering its interactions with other species in the ecosystem or changes in farm practices.

So, what can pasture managers do to prepare for the multiple interacting uncertainties associated with climate change? The most important need is for an integrated approach to predicting, preparing for, and responding to climate change in agriculture involving a wide range of expertise, including farm systems, plant and animal breeding, entomology and biosecurity, agronomy and weed science. A first step towards this integrated approach would be to increase adoption of IPM for pasture pests, as suggested by Mansfield et al. (2019). Mason et al. (2017) considered that increased plant community diversity, particularly including drought-tolerant species, could help enhance certainty of pasture production under climate change. This diversity may help with pest management, such as providing refugia for biological control agents, whereas multi-species pastures may provide an improved food source for polyphagous insect pests. Another factor to consider in the management of pests under future climate change scenarios, particularly if there are more frequent outbreak episodes, is the use of synthetic chemicals. The use of these important tools is under pressure from consumers who are increasingly demanding products 
that have been treated with fewer or no chemical pesticides, and some are prepared to pay premiums for products from pesticide-free farm systems.

\section{Conclusions}

Pests and all trophic levels of the pastures they live in are already responding to climate change and will continue to do so. While biological resilience is innate, the ability of pastoral systems to be resilient and remain productive - in terms of economic, environmental and social outcomes - is a serious issue under climate change. It is important for the pastoral sector to identify priorities for future research into climate change impacts on pasture pests - should the focus be on integrating pest resilience into farm systems (e.g., resilient forages, natural enemy refugia) in the more vulnerable regions, such as the northern North Island? Or should the focus be on specific pests that are likely to become even more damaging in response to climate change, such as black beetle? Clearly, future pest mitigation options are not simple and will require research based on a systems approach that includes perspectives from the farm to the consumer, as well as detailed studies of pest species to improve our ability to predict climate change effects at the species level. Future funding models must be designed to include this transdisciplinarity and ensure that the impacts of insect pests on pastoral systems are an integral part of the process - not just an afterthought that "requires future research".

\section{ACKNOWLEDGEMENTS}

Thanks to Dr Robyn Dynes (AgResearch) for discussions about the impact of climate change on farm systems, Dr Warren King (AgResearch) and the Global Biodiversity Information Facility (GBIF 2019) for access to black beetle distribution records. The plantain moth case study was based on projects funded by Beef + Lamb New Zealand (FITT Project A20551), Ministry for Primary Industries Sustainable Farming Fund (Project 404890), DairyNZ (Project BP1504), PGG Wrightson Seeds, Grasslanz Technology Ltd. and the New Zealand Ministry for Business, Innovation and Employment through LINX0804 Ecosystems Bioprotection. The Flores weevil case study was funded by AgResearch (SSIF: Effect of climate change on potential future pests).

\section{REFERENCES}

Abdallah M, Mwatawala MW, Kudra AB. 2016. Abundance and dispersal of Heteronychus arator (Coleoptera: Scarabaeidae) in maize fields under different fertilizer treatments. SpringerPlus 5: 1-9. https://doi.org/10.1186/s40064-016-1847-8

Ainsworth EA, Long SP. 2005. What have we learned from 15 years of free-air $\mathrm{CO}_{2}$ enrichment
(FACE)? A meta-analytic review of the responses of photosynthesis, canopy properties and plant production to rising $\mathrm{CO}_{2}$. New Phytologist 165: 351-372. https://doi.org/10.1111/j.14698137.2004.01224.x

Ainsworth EA, Rogers A. 2007. The response of photosynthesis and stomatal conductance to rising $\left[\mathrm{CO}_{2}\right]$ : mechanisms and environmental interactions. Plant, Cell \& Environment 30: 258-270. https://doi. org/10.1111/j.1365-3040.2007.01641.x

Anon. 2020. CABI Invasive Species Compendium Heteronychus arator. Retrieved 10 November 2020 from: https://www.cabi.org/isc/datasheet/27067

Atijegbe SR. 2019. Niche differentiation within the Wiseana (porina) species complex: pasture pests of New Zealand. PhD. thesis, Lincoln University, Lincoln, New Zealand. 208 p. http://researcharchive. lincoln.ac.nz/handle/10182/10894

Bailey PT. 2007. Pests of field crops and pastures: identification and control. CSIRO Publishing, Australia. 520 p. https://doi. org/10.1071/9780643095328

Bell N, Townsend R, Popay A, Mercer C, Jackson T. 2011. Black beetle: lessons from the past and options for the future. In: Mercer CF. Ed. Pasture Persistence Symposium. Grassland Research and Practice Series 15. Dunedin, New Zealand: New Zealand Grassland Association, pp. 119-124. https://doi.org/10.33584/ rps.15.2011.3193

Cameron PJ, Shelton AM, Walker GP, Tang JD. 1997. Comparative insecticide resistance of New Zealand and North American populations of diamondback moth, Plutella xylostella (Lepidoptera: Plutellidae). New Zealand Journal of Crop and Horticultural Science 25: 117-122. https://doi.org/10.1080/01140 671.1997.9513997

Carlton AJ, Cameron KC, Di HJ, Edwards GR, Clough TJ. 2019. Nitrate leaching losses are lower from ryegrass/white clover forages containing plantain than from ryegrass/white clover forages under different irrigation. New Zealand Journal of Agricultural Research 62: 150-172. https://doi.org/1 $0.1080 / 00288233.2018 .1461659$

Coll M, Hughes L. 2008. Effects of elevated $\mathrm{CO}_{2}$ on an insect omnivore: A test for nutritional effects mediated by host plants and prey. Agriculture, Ecosystems \& Environment 123: 271-279. https:// doi.org/10.1016/j.agee.2007.06.003

Dancau T, Mason PG, Cappuccino N. 2018. Elusively overwintering: a review of diamondback moth (Lepidoptera: Plutellidae) cold tolerance and overwintering strategy. The Canadian Entomologist 150: 156-173. https://doi.org/10.4039/tce.2018.2

De Barro P. 1995. Bemisia tabaci biotype B: a review of its biology, distribution and control [Report 36]. 
CSIRO Division of Entomology, Canberra, Australia. $58 \mathrm{p}$.

De Barro P. 2002. Emerald, a post mortem. Proceedings of the 11th Australian Cotton Conference. Australian Cotton Growers' Research Association, Brisbane, Queensland, Australia, pp. 735-742.

De Klerk N. 2015. Early warning system for the black maize beetle (Heteronychus arator Fabricius) in a major maize producing region of South Africa. MSc. thesis, University of the Free State, Bloemfontein, South Africa. $113 \mathrm{p}$.

Dodd MB, Chapman DF, Ogle G. 2018. Regrassing trends and drivers in the New Zealand dairy industry. Journal of New Zealand Grasslands: 177-184. https://doi.org/10.33584/jnzg.2018.80.342

Dodd M, Dalley D, Wims C, Elliott D, Griffin A. 2019. A comparison of temperate pasture species mixtures selected to increase dairy cow production and reduce urinary nitrogen excretion. New Zealand Journal of Agricultural Research 62: 504-527. https://doi.org/1 $0.1080 / 00288233.2018 .1518246$

Dosdall LM, Zalucki MP, Tansey JA, Furlong MJ. 2012. Developmental responses of the diamondback moth parasitoid Diadegma semiclausum (Hellén) (Hymenoptera: Ichneumonidae) to temperature and host plant species. Bulletin of Entomological Research 102: 373-384. https://doi.org/10.1017/ S0007485311000708

Du Plessis H, Schlemmer M-L, Van den Berg J. 2020. The effect of temperature on the development of Spodoptera frugiperda (Lepidoptera: Noctuidae). Insects 11: 228. https://doi.org/10.3390/ insects 11040228

Dugdale JS. 1994. Hepialidae (Insecta: Lepidoptera). Fauna of New Zealand 30. Manaaki Whenua Press, Lincoln, Canterbury, New Zealand. 164 p. https:// www.biotaxa.org/fnz/article/download/fnz.30/2954

Dynes R, Payn T, Brown H, Bryant J, Newton P, Snow V, Lieffering M, Wilson D, Beets P. 2010. New Zealand's land-based primary industries \& climate change: Assessing adaptation through scenario-based modelling. In: Nottage RAC, Wratt DS, Bornman JF \& Jones K. Eds. Climate change adaptation in New Zealand: future scenarios and some sectoral perspectives. Wellington, New Zealand: New Zealand Climate Change Centre, NIWA, pp. 44-55.

East R, Willoughby BE. 1980. Effects of pasture defoliation in summer on grass grub (Costelytra zelandica) populations. New Zealand Journal of Agricultural Research 23: 547-562. https://doi.org/1 0.1080/00288233.1980.10417882

Edney-Browne E, Brockerhoff EG, Ward D. 2018. Establishment patterns of non-native insects in New Zealand. Biological Invasions 20: 1657-1669. https:// doi.org/10.1007/s10530-017-1652-5
Ehau-Taumaunu H. 2017. Uncovering microbiota profiles and traditional Máori host plants of Wiseana spp. in New Zealand. MSc. thesis, University of Auckland, Auckland, New Zealand. https:// researchspace.auckland.ac.nz/handle/2292/33774

Essen M. 1975. Notes on the biology and distribution of three recently discovered exotic weevils in Hawkes Bay. Proceedings of the 28th New Zealand Weed and Pest Control Conference: 208-212. https://doi. org/10.30843/nzpp.1975.28.9157

Eziah VY, Rose HA, Clift AD, Mansfield S. 2008. Susceptibility of four field populations of the diamondback moth Plutella xylostella L. (Lepidoptera: Yponomeutidae) to six insecticides in the Sydney region, New South Wales, Australia. Australian Journal of Entomology 47: 355-360. https://doi.org/10.1111/j.1440-6055.2008.00668.x

Fajer ED, Bowers MD, Bazzaz FA. 1989. The effects of enriched carbon dioxide atmospheres on plant-insect herbivore interactions. Science 243: 1198-1200. https://doi.org/10.1126/science.243.4895.1198

Ferguson CM, Barratt BIP, Bell N, Goldson SL, Hardwick S, Jackson M, Jackson TA, Phillips CB, Popay AJ, Rennie G, Sinclair S, Townsend R, Wilson M. 2019. Quantifying the economic cost of invertebrate pests to New Zealand's pastoral industry. New Zealand Journal of Agricultural Research 62: 255-315. https:// doi.org/10.1080/00288233.2018.1478860

Ferguson C, Crook K. 2004. The development of two Wiseana species and the implications for their management as pastoral pests. In: Winder LM \& Goldson SL. Eds. Proceedings of the 8th Australasian Grassland Invertebrate Ecology Conference. AgResearch, Lincoln, New Zealand, pp. 87-93.

Ferguson C, Gee-Taylor M, Richards N. 2016. February/ March moth flights in Manawatu have important implications for porina management. New Zealand Plant Protection 69: 327. https://doi.org/10.30843/ nzpp.2016.69.5939

Fick SE, Hijmans RJ. 2017. WorldClim 2: new $1 \mathrm{~km}$ spatial resolution climate surfaces for global land areas. International Journal of Climatology 37: 4302-4315. https://doi.org/10.1002/joc.5086

Frank SD, Just MG. 2020. Can cities activate sleeper species and predict future forest pests? A case study of scale insects. Insects 11: 142. Multidisciplinary Digital Publishing Institute. https://doi.org/10.3390/ insects11030142

Furlong MJ, Zalucki MP. 2017. Climate change and biological control: the consequences of increasing temperatures on host-parasitoid interactions. Current Opinion in Insect Science 20: 39-44. https://doi. org/10.1016/j.cois.2017.03.006

GBIF. 2019. Heteronychus arator (Fabricius, 1775) https://www.gbif.org/species/4995411 
Gerard P, Barringer JR, Charles J, Fowler S, Kean J, Phillips C, Tait A, Walker G. 2013a. Potential effects of climate change on biological control systems: case studies from New Zealand. Biocontrol 58: 149-162. https://doi.org/10.1007/s10526-012-9480-0

Gerard P, Bell N, Eden T, King W, Mapp N, Pirie M, Rennie G. 2013b. Influence of pasture renewal, soil factors and climate on black beetle abundance in Waikato and Bay of Plenty. Proceedings of the New Zealand Grassland Association 75: 235-240. https:// doi.org/10.33584/jnzg.2013.75.2904

Gerard PJ, Philip BA, Ferguson CM, Eden TM. 2018a. Oviposition and development of two plantain pests, Scopula rubraria and Epyaxa rosearia (Lepidoptera: Geometridae). New Zealand Journal of Agricultural Research 61: 414-424. https://doi.org/10.1080/00288 233.2017.1400445

Gerard P, Schwendel BH, Fraser K, Eden T. 2018b. Effect of narrow-leaved plantain cultivar on development of two geometrid pests, Scopula rubraria and Epyaxa rosearia. New Zealand Journal of Agricultural Research 61: 403-413. https://doi.org /10.1080/00288233.2017.1398763

Goldson SL. 2006. Climate change and biological control. In: Newton PCD, Carran RA, Edwards GR, Niklaus PA. Eds. Agroecosystems in a changing environment. New York, CRC Press, pp. 329-332

Goldson SL, Barker GM, Chapman HM, Popay AJ, Stewart AV, Caradus JR, Barratt BI. 2020. Severe insect pest impacts on New Zealand pasture: The plight of an ecological outlier. Journal of Insect Science 20: 1-17. https://doi.org/10.1093/jisesa/ ieaa 018

Hardwick S, Baltus JG, Willoughby BE. 2000. Seasonal distribution of Herpetogramma licarsisalis (Walker) (Lepidoptera: Pyralidae) in northern Northland. New Zealand Entomologist 23: 77-83. https://doi.org/10.1 080/00779962.2000.9722071

Harrington J. 1964. The geographical distribution of the black maize beetle, Heteronychus sanctae-helenae Blanchard (Coleoptera: Scarabaeidae). Journal of the Entomological Society of Southern Africa 26: 438-440.

Hijioka Y, Matsuoka Y, Nishimoto H, Masui M, Kainuma M. 2008. Global GHG emissions scenarios under GHG concentration stabilization targets. Journal of Global Environmental Engineering 13: 97-108.

Hill MP, Hoffmann AA, Macfadyen S, Umina PA, Elith J. 2012a. Understanding niche shifts: using current and historical data to model the invasive redlegged earth mite, Halotydeus destructor: Investigating niche shifts in an invasive mite. Diversity and Distributions 18: 191-203. https://doi.org/10.1111/ j.1472-4642.2011.00844.x
Hill MP, Hoffmann AA, McColl S, Umina PA. 2012b. Distribution of cryptic blue oat mite species in Australia: current and future climate conditions. Agricultural and Forest Entomology 14: 127-137. https://doi.org/10.1111/j.14619563.2011.00544.x

Horrocks A, Horne PA, Davidson MM. 2018. Demonstrating an integrated pest management strategy in forage- and seed-brassica crops using a collaborative approach. New Zealand Plant Protection 71: 112-120. https://doi.org/10.30843/ nzpp.2018.71.118

Hulme PE. 2017. Climate change and biological invasions: evidence, expectations, and response options: Alien species and climate change in Great Britain. Biological Reviews 92: 1297-1313. https:// doi.org/10.1111/brv.12282

IPCC. 2000. Emissions Scenarios Report. Nakicenovic N \& Swart R. Eds. Cambridge University Press, Cambridge, England. 570 p. https://www.ipcc.ch/ report/emissions-scenarios/

Jackson TA, Klein MG. 2006. Scarabs as pests: a continuing problem. The Coleopterists Bulletin 60: 102119. https://doi.org/10.1649/0010-065X(2006)60[10 2:SAPACP]2.0.CO;2

Kalaugher E, Beukes P, Bornman JF, Clark A, Campbell DI. 2017. Modelling farm-level adaptation of temperate, pasture-based dairy farms to climate change. Agricultural Systems 153: 53-68. https://doi. org/10.1016/j.agsy.2017.01.008

Kalaugher E, Bornman JF, Clark A, Beukes P. 2013. An integrated biophysical and socio-economic framework for analysis of climate change adaptation strategies: the case of a New Zealand dairy farming system. Environmental Modelling \& Software 39: 176-187. https://doi.org/10.1016/j. envsoft.2012.03.018

Kalmakoff J, Fleming S, Archibald S, Stewart K. 1985. The porina story: a stochastic model. In: Chapman RB. Ed. Proceedings of the 4th Australasian Conference on Grassland Invertebrate Ecology. Lincoln College, University College of Agriculture, Canterbury, New Zealand: Caxton Press, pp. 160166.

King PD, Mercer CF, Meekings JS. 1981a. Ecology of black beetle, Heteronychus arator (Coleoptera: Scarabaeidae)-population studies. New Zealand Journal of Agricultural Research 24: 87-97. https:// doi.org/10.1080/00288233.1981.10420876

King PD, Mercer CF, Meekings JS. 1981b. Ecology of black beetle, Heteronychus arator (Coleoptera: Scarabaeidae) - influence of temperature on feeding, growth, and survival of the larvae. New Zealand Journal of Zoology 8: 113-117. https://doi. org/10.1080/03014223.1981.10427948 
King PD, Mercer CF, Meekings JS. 1981c. Ecology of black beetle, Heteronychus arator (Coleoptera: Scarabaeidae) - population modelling. New Zealand Journal of Agricultural Research 24: 99-105. https:// doi.org/10.1080/00288233.1981.10420877

Kleynhans C, Thirion C, Moolman J. 2005. A level I river ecoregion classification system for South Africa, Lesotho and Swaziland. Department of Water and Sanitation, Republic of South Africa. http:// www.dwa.gov.za/iwqs/gis_data/ecoregions/getecoregions.aspx

Lanteri A, Guzmán N, Río MD, Confalonieri V. 2013. Potential geographic distributions and successful invasions of parthenogenetic broad-nosed weevils (Coleoptera: Curculionidae) native to South America. Environmental Entomology 42: 677-687. https://doi. org/10.1603/EN12297

Lieffering M, Newton PC, Vibart R, Li FY. 2016. Exploring climate change impacts and adaptations of extensive pastoral agriculture systems by combining biophysical simulation and farm system models. Agricultural Systems 144: 77-86. https://doi. org/10.1016/j.agsy.2016.01.005

Liu T-X, Sparks AN, Chen W. 2003. Toxicity, persistence and efficacy of indoxacarb and two other insecticides on Plutella xylostella (Lepidoptera: Plutellidae) immatures in cabbage. International Journal of Pest Management 49: 235-241. https:// doi.org/10.1080/0967087031000101070

Macfadyen S, McDonald G, Hill MP. 2018. From species distributions to climate change adaptation: Knowledge gaps in managing invertebrate pests in broad-acre grain crops. Agriculture, Ecosystems \& Environment 253: 208-219. https://doi.org/10.1016/j. agee.2016.08.029

Mansfield S, Ferguson CM, White T, Hardwick S, Marshall SDG, Zydenbos SM, Heimoana SC, Gorddard R, Whitehouse MEA. 2019. Barriers to IPM adoption for insect pests in New Zealand pastures. Journal of New Zealand Grasslands 81: 139-148. https://doi.org/10.33584/jnzg.2019.81.383

Mason NW, Palmer DJ, Romera A, Waugh D, Mudge PL. 2017. Combining field experiments and predictive models to assess potential for increased plant diversity to climate-proof intensive agriculture. Ecology and Evolution 7: 4907-4918. https://doi. org/10.1002/ece3.3028

Massad TJ, Dyer LA. 2010. A meta-analysis of the effects of global environmental change on plantherbivore interactions. Arthropod-Plant Interactions 4: 181-188. https://doi.org/10.1007/s11829-0109102-7

Matthiessen J, Ridsdill-Smith T. 1991. Populations of African black beetle, Heteronychus arator (Coleoptera: Scarabaeidae) in a Mediterranean climate region of Australia. Bulletin of Entomological Research 81: 85-91. https://doi.org/10.1017/ S000748530005327X

Meudt H. 2012. A taxonomic revision of native New Zealand Plantago (Plantaginaceae). New Zealand Journal of Botany 50: 101-178. https://doi.org/10.1 080/0028825X.2012.671179

Ministry for the Environment. 2018. Climate Change Projections for New Zealand: Atmosphere Projections Based on Simulations from the IPCC Fifth Assessment, 2nd Edition. Wellington: [Report ME 1385]. Ministry for the Environment, Wellington, New Zealand. 131 p. https://www. mfe.govt.nz/publications/climate-change/climatechange-projections-new-zealand

Ministry for the Environment. 2019. Likely climate change impacts in New Zealand. Retrieved 9 August 2021 from: https://environment.govt.nz/facts-andscience/climate-change/impacts-of-climate-changeper-region/projections-west-coast-region/\#rainfall

Muir PD, Thomson BC, Smith NB, Ward KR, MacGillivray L, Macfarlane MJ. 2019. The performance and profitability of plantain/clover pasture mixtures in East Coast farming systems. Journal of New Zealand Grasslands: 81-86. https:// doi.org/10.33584/jnzg.2019.81.396

Nagoshi RN, Htain NN, Boughton D, Zhang L, Xiao Y, Nagoshi BY, Mota-Sanchez D. 2020. Southeastern Asia fall armyworms are closely related to populations in Africa and India, consistent with common origin and recent migration. Scientific Reports 10: 1421. https://doi.org/10.1038/s41598-020-58249-3

Newton PC, Lieffering M, Parsons AJ, Brock SC, Theobald PW, Hunt CL, Luo D, Hovenden MJ. 2014. Selective grazing modifies previously anticipated responses of plant community composition to elevated $\mathrm{CO} 2$ in a temperate grassland. Global Change Biology 20: 158-169. https://doi.org/10.1111/ gcb. 12301

NIWA. 2020. CliFlo web access to the national climate database. https://cliflo.niwa.co.nz/

O'Callaghan M, Jackson T, Noonan M. 1989. Ecology of Serratia entomophila in soil. In: Stahle PP. Ed. Proceedings of the 5th Australasian conference on grassland invertebrate ecology. D.D. Printing, Melbourne, Australia. pp. 69-75

Peng W, Ma NL, Zhang D, Zhou Q, Yue X, Khoo SC, Yang H, Guan R, Chen H, Zhang X. 2020. A review of historical and recent locust outbreaks: Links to global warming, food security and mitigation strategies. Environmental Research 191: 110046. https://doi.org/10.1016/j.envres.2020.110046

Philip BA, Ferguson CM. 2014. Larval development of the plantainfeeding moth Scopula rubraria (Doubleday) (Lepidoptera Geometridae). New 
Zealand Plant Protection 67: 327. https://doi. org/10.30843/nzpp.2014.67.5770

Ramirez-Cabral NYZ, Kumar L, Shabani F. 2017. Global alterations in areas of suitability for maize production from climate change and using a mechanistic species distribution model (CLIMEX). Scientific Reports 7: 5910. https://doi.org/10.1038/ s41598-017-05804-0

Richards NK, Mansfield S, Townsend RJ, Ferguson CM. 2017. Genetic variation within species and haplotypes of the Wiseana (Lepidoptera: Hepialidae) complex and development of non-sequenced based identification tools to aid field studies. Pest Management Science 73: 2334-2344. https://doi. org $/ 10.1002 /$ ps. 4620

Ridsdill-Smith T. 1991. A contribution to assessing the economic impact of redlegged earth mite on agricultural production in Australia. Plant Protection Quarterly 6: 168-169.

Ridsdill-Smith T. 1997. Biology and control of Halotydeus destructor (Tucker) (Acarina: Penthaleidae): a review. Experimental \& Applied Acarology 21: 193-223. https://doi. org/10.1023/A:1018490703897

Ridsdill-Smith J, Pavri C, De Boer E, Kriticos D. 2005. Predictions of summer diapause in the redlegged earth mite, Halotydeus destructor (Acari: Penthaleidae), in Australia. Journal of Insect Physiology 51: 717-726. https://doi.org/10.1016/j.jinsphys.2005.04.014

Rodriguero MS, Guzmán NV, Lanteri AA, Confalonieri VA. 2019. The effect of reproductive system on invasiveness: Lessons from South American weevils. Florida Entomologist 102: 495. https://doi. org/10.1653/024.102.0309

Schreven SJJ, Frago E, Stens A, de Jong PW, van Loon JJA. 2017. Contrasting effects of heat pulses on different trophic levels, an experiment with a herbivore-parasitoid model system. PLOS ONE 12: e0176704. https://doi.org/10.1371/journal. pone. 0176704

Scott RR. 1984. New Zealand pest and beneficial insects. Lincoln University College of Agriculture, Christchurch, New Zealand. 373 p.

Shelton AM, Robertson JL, Tang JD, Perez C, Eigenbrode SD, Preisler HK, Wilsey WT, Cooley RJ. 1993. Resistance of diamondback moth (Lepidoptera: Plutellidae) to Bacillus thuringiensis subspecies in the field. Journal of Economic Entomology 86: 697705. https://doi.org/10.1093/jee/86.3.697

Simon PL, de Klein CA, Worth W, Rutherford AJ, Dieckow J. 2019. The efficacy of Plantago lanceolata for mitigating nitrous oxide emissions from cattle urine patches. Science of the Total Environment 691: 430-441. https://doi.org/10.1016/j. scitotenv.2019.07.141
Talekar NS, Shelton AM. 1993. Biology, ecology, and management of the diamondback moth. Annual Review of Entomology 38: 275-301. https://doi. org/10.1146/annurev.en.38.010193.001423

Townsend RJ, McNeill MR, Jackson TA. 2008. Australian black beetle expansion through Christchurch city highlights a risk to pastoral agriculture on the Canterbury Plains. New Zealand Plant Protection 61: 388. https://doi.org/10.30843/ nzpp.2008.61.6859

Tozer K, Barker G, Cameron C, Wilson D, Loick N. 2016. Effects of including forage herbs in grasslegume mixtures on persistence of intensively managed pastures sampled across three age categories and five regions. New Zealand Journal of Agricultural Research 59: 250-268. https://doi.org/1 0.1080/00288233.2016.1188831

Umina PA, Hoffmann AA. 1999. Tolerance of cryptic species of blue oat mites (Penthaleus spp.) and the redlegged earth mite (Halotydeus destructor) to pesticides. Australian Journal of Experimental Agriculture 39: 621-628. https://doi.org/10.1071/ EA99028

Umina PA, Hoffmann AA. 2003. Diapause and implications for control of Penthaleus species and Halotydeus destructor (Acari: Penthaleidae) in southeastern Australia. Experimental and Applied Acarology 31: 209-223. https://doi.org/10.1023/ B:APPA.0000010378.91111.16

Umina PA, Hoffmann AA. 2004. Plant host associations of Penthaleus species and Halotydeus destructor (Acari: Penthaleidae) and implications for integrated pest management. Experimental and Applied Acarology 33: 1-20. https://doi.org/10.1023/ B:APPA.0000030014.00162.44

Walker GP, Davis SI, MacDonald FH, Herman TJB. 2012. Update on diamondback moth (Plutella xylostella) insecticide resistance and the vegetable brassica insecticide management strategy. New Zealand Plant Protection 65: 114-119. https://doi. org/10.30843/nzpp.2012.65.5397

Walker JTS, Suckling DM, Wearing CH. 2017. Past, present, and future of integrated control of apple pests: the New Zealand experience. Annual Review of Entomology 62: 231-248. https://doi.org/10.1146/ annurev-ento-031616-035626

Walker G, Wright P, Cameron P, Fletcher J, Walker M, Bulman S, Berry N. 2016. Pests, natural enemies, diseases and disorders of vegetable brassicas in New Zealand. Vegetables NZ Inc. and The New Zealand Institute for Plant and Food Research Limited, Mt Albert, Auckland, New Zealand. 119 p. https://www.freshvegetables.co.nz/assets/ J005621-HANDBOOK-Brassica-FINAL-medres. pdf 
Watson R. 1980. Dispersal and distribution of Heteronychus arator in New Zealand (Coleoptera: Scarabaeidae). In: Crosby TK \& Pottinger RP. Eds. Proceedings of the 2nd Australasian conference on grassland invertebrate ecology. Wellington, New Zealand: Government Printer, pp. 149-152.

Weeks AR, Fripp YJ, Hoffmann AA. 1995. Genetic structure of Halotydeus destructor and Penthaleus major populations in Victoria (Acari: Penthaleidae). Experimental and Applied Acarology 19: 633-646. https://doi.org/10.1007/BF00145252

Weeks AR, Hoffmann AA. 1999. The biology of Penthaleus species in southeastern Australia. Entomologia Experimentalis et Applicata 92: 179-189. https://doi.org/10.1046/j.15707458.1999.00537.x

Woodward SJ, Van Oijen M, Griffiths WM, Beukes PC, Chapman DF. 2020. Identifying causes of low persistence of perennial ryegrass (Lolium perenne) dairy pasture using the Basic Grassland model
(BASGRA). Grass and Forage Science 75: 45-63. https://doi.org/10.1111/gfs.12464

Woodward S, Waghorn G, Bryant M, Benton A. 2012. Can diverse pasture mixtures reduce nitrogen losses? In: Jacobs J. Ed. Proceedings of the $5^{\text {th }}$ Australasian Dairy Science Symposium. Tallygaroopna, Victoria, Australia: Australasian Dairy Science Symposium, pp. 463-464.

Zalucki MP, Shabbir A, Silva R, Adamson D, ShuSheng L, Furlong MJ. 2012. Estimating the economic cost of one of the world's major insect pests, Plutella xylostella (Lepidoptera: Plutellidae): Just how long is a piece of string? Journal of Economic Entomology 105: 1115-1129. https://doi. org/10.1603/EC12107

Zvereva EL, Kozlov MV. 2006. Consequences of simultaneous elevation of carbon dioxide and temperature for plant-herbivore interactions: a metaanalysis. Global Change Biology 12: 27-41. https://doi.org/10.1111/j.1365-2486.2005.01086.x 